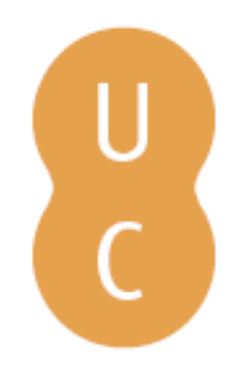

\title{
pompalina
}

\section{Luís da Cruz e companhia na correspondência de Manuel Correia}

Autor(es): $\quad$ Barbosa, Manuel José de Sousa

Publicado por: Imprensa da Universidade de Coimbra; Sapienza. Universitá di Roma

URL

persistente: $\quad$ URI:http://hdl.handle.net/10316.2/38770

DOI: $\quad$ DOI:http://dx.doi.org/10.14195/978-989-721-044-0_3

Accessed : $\quad$ 26-Apr-2023 14:06:42

A navegação consulta e descarregamento dos títulos inseridos nas Bibliotecas Digitais UC Digitalis, UC Pombalina e UC Impactum, pressupõem a aceitação plena e sem reservas dos Termos e Condições de Uso destas Bibliotecas Digitais, disponíveis em https://digitalis.uc.pt/pt-pt/termos.

Conforme exposto nos referidos Termos e Condições de Uso, o descarregamento de títulos de acesso restrito requer uma licença válida de autorização devendo o utilizador aceder ao(s) documento(s) a partir de um endereço de IP da instituição detentora da supramencionada licença.

Ao utilizador é apenas permitido o descarregamento para uso pessoal, pelo que o emprego do(s) título(s) descarregado(s) para outro fim, designadamente comercial, carece de autorização do respetivo autor ou editor da obra.

Na medida em que todas as obras da UC Digitalis se encontram protegidas pelo Código do Direito de Autor e Direitos Conexos e demais legislação aplicável, toda a cópia, parcial ou total, deste documento, nos casos em que é legalmente admitida, deverá conter ou fazer-se acompanhar por este aviso. 


\section{Aires Barbosa na}

\section{Cosmopólis Renascentista}

Italo Pantani, Margarida Miranda \& Henrique Manso (coordenadores)

IMPRENSA DA UNIVERSIDADE DE COIMBRA

SAPIENZA. UNIVERSITÁ DI ROMA 


\title{
Luís da CRUZ E COMPANHIA NA CORRESPONDÊNCIA DE Manuel Correia
}

\author{
Manuel José de Sousa Barbosa \\ Universidade de Lisboa
}

Este estudo mais não pretende ser do que uma mera sensibilização para um estudo mais aprofundado do nosso humanismo nos finais do século XVI e inícios do XVII, um século após o tempo em que haviam pontificado figuras bem sonantes que projectaram além fronteiras o nome do nosso país. Lembremo-nos só, entre outros, de Henrique Caiado e do aveirense Aires Barbosa, este último aqui evocado hoje duma forma especial.

Em finais do séc. XVI, o humanismo continuava a florescer mas, como não podia deixar de ser, com outros cambiantes, fruto de novas circunstâncias históricas. A abordagem e recuperação do legado literário da Antiguidade greco-latina efectuada durante o séc. XV sobretudo em Itália, donde irradiava para o resto do continente europeu, prosseguiu no séc.XVI, mas agora associada a constrangimentos sociais específicos que afectaram praticamente toda a Europa. Refiro-me, claro está, às repercussões sociais advindas dos movimentos da Reforma e Contra-reforma, que transbordaram ainda para o século XVII. O movimento humanista, porém, enquanto busca de modelos de imitação na Antiguidade greco-latina, prosseguiu dos dois lados da barricada da Fé cristã. Se os dogmas provocavam divisões que não deixariam de se reflectir em certos aspectos da abordagem dos autores antigos, comum continuava a ser a crença, num e noutro lado, na importância da leitura desses autores. A literatura antiga constituía sempre um terreno que compensava explorar e dar a explorar.

Que se passava então em Portugal em finais do século XVI no que ao movimento humanista diz respeito? Será que pouco há a investigar, impondose antecipadamente, como desencorajadora de tal investigação, a perspectiva duma paisagem pouco variada, onde os Jesuítas ocupariam na prática toda a cena, prometendo de lá não sair tão cedo? De facto, nesta altura, o ensino está, em grande parte, em suas mãos, com uma rede bem espalhada de colégios nas principais cidades, ${ }^{1}$ e um método pedagógico solidamente implantado. ${ }^{2}$

\footnotetext{
${ }^{1} \mathrm{Na}$ transição do século XVI para o XVII, os Jesuítas possuíam colégios em Coimbra, Lisboa, Évora, Porto, Braga, Bragança, Faro, Santarém, Funchal, Angra, Luanda, Goa e Macau. Sobre esta matéria, cf. Lúcio Craveiro da Silva, "Os Jesuítas e o ensino secundário”, Brotéria, 31, 1940, 476-486; Francisco Rodrigues, História da Companbia de Jesus na assistência de Portugal, Porto, 1931-1950 (7 vols.), II, pp. 11-46.

${ }^{2}$ Estamos a referir-nos ao Ratio studiorum ("Plano de estudos" / "Método de estudos") consagrado como a magna carta do ensino nos colégios dos Jesuítas em 1599, após uma fase de sucessivas experimentações partilhadas e reflectidas ao longo de quase meio século.
} 
Os testemunhos deste humanismo escolar jesuíta sobrevivem em colecções de códices, geralmente incompletas, relativas aos vários colégios, códices esses que constituem, na sua essência, um repositório de composições poéticas e

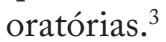

É inegável que na transição do séc. XVI para o XVII o humanismo português tinha na Companhia de Jesus a grande protagonista, com uma força que irradiava além fronteiras. Da gramática do P. Manuel Álvares e da sua intensa utilização em todo o mundo, com incontáveis edições, nem vale a pena falar, por ser questão sobejamente conhecida. ${ }^{4}$ Luís da Cruz é outra figura em evidência. A sua fama de grande poeta estava já consolidada internacionalmente, e ainda nem publicara o seu teatro. Acabara de editar, no ano de 1597, em Ingolstadt a sua Interpretatio poetica dos Salmos, obra que conheceria de imediato grande sucesso na Europa, como facilmente se conclui pelo número de reedições que mereceu em pouco tempo, em diversas cidades. ${ }^{5}$ Esta obra veio à luz com o elogio dum reputado humanista, Marco António Mureto, a quem se pedira parecer para a publicação da obra, tendo ele deixado registado que os ritmos eram simples, harmoniosos e muito agradáveis ao ouvido. ${ }^{6}$ Quanto à sua obra teatral, ela viria, como se sabe, a ser editada em Lyon em 1605, na oficina de Horácio Cardon. ${ }^{7}$

Mas não ficou por aqui a atenção dada a este grande expoente do humanismo escolar jesuíta em Portugal. Luís da Cruz cultivou a poesia em várias vertentes: paráfrase bíblica, lírica de tipo horaciano, ${ }^{8}$ epigramas, enigmas e, sobretudo, o teatro, nos subgéneros da tragédia, da tragicomédia, da comédia

${ }^{3}$ Do Colégio das Artes de Coimbra conhecemos os vários tomos das Rerum Scholasticarum, hoje dispersos pela Biblioteca Nacional de Portugal (cod. 3308, o "tomus primus"), pela Biblioteca Geral da Universidade de Coimbra (Cod. 993, o "tomus secundus", e o Cod. 994, o "tomus quintus") e pelos Arquivos Nacionais da Torre do Tombo (Livraria, Cod. 1963, o "tomus sextus"). Do Colégio de Évora restam igualmente alguns tomos duma série intitulada "Acta publice in Academia Eborensi" a que se ligam os códices CVIII/2-7 e CVIII/2-8, da Biblioteca Pública de Évora, e o Cod. 4515, da Biblioteca Nacional de Portugal.

${ }^{4}$ Podemos ver nos vols. XIII e XIV da revista Humanitas, em apêndice, o quadro compilado de Sommervogel pelo P. ${ }^{e}$ Emílio Springhetti, que regista quinhentas e trinta edições em vinte e dois países, incluindo o México, a China e o Japão, fora da Europa.

${ }_{5}$ Interpretatio poetica latine in centum quinquaginta psalmos, autore Ludouico Crucio Olysipponensi. Ingolstadii, excudebat Adam Sartorius. Anno M.D.XCVII. A esta editio princeps seguir-se-iam as edições de Madrid (1600), de Nápoles (1601), de Milão (1604) de Veneza (1604) e de Colónia (1612).

${ }^{6} \mathrm{C}$. prefácio inédito “Ad beneuolum eruditumque lectorem”, §21 in Manuel Barbosa, "Luís da Cruz e a poética teatral dos Jesuítas: o prefácio que ficou inédito" Euphrosyne 28 (2000), p. 401.

${ }^{7}$ Tragicae comicaeque actiones a Regio Artium Collegio Societatis IESV, datae Conimbricae in publicum theatrum, auctore Ludouico Crucio eiusdem Societatis olisiponensi, nunc primum in lucem editae et sedulo diligenterque recognitae. Cum privilegio. Lugduni, apud Horatium Cardon, 1605.

${ }^{8}$ Podemos incluir a paráfrase bíblica na lírica de tipo horaciano, uma vez que na sua Interpretatio os salmos são vertidos em metros horacianos. 
e da écloga. ${ }^{9}$ No domínio da prosa conhecemos-lhe dois discursos em louvor da Rainha Santa Isabel, os prefácios poéticos ao seu teatro e o De uita et moribus Dominici, uma biografia em três livros do Irmão Domingos João. ${ }^{10}$ Estou em crer que esta biografia, de que pouco se fala, terá sido a primeira obra de Luís da Cruz a merecer tradução em português, por obra do P. Francisco Macedo. ${ }^{11}$ No elenco das suas obras manuscritas indicadas no Sommervogel, relativas ao tempo em que ainda era Jesuíta e estava em Coimbra, surge a seguinte indicação: Vita Dominici Ioannis, e Societate Iesu, Laici Adjutoris. (En latin et en portuguais.). ${ }^{12}$

O grande trabalho literário de pedagogo desenvolvido por Luís da Cruz iria ter continuação nos tempos mais próximos, dentro da Companhia de Jesus, na obra de discípulos seus, e não apenas no campo teatral, em que merecem referência os nomes de João da Rocha e de Afonso Mendes, futuro Patriarca da Etiópia, ${ }^{13}$ mas igualmente no domínio da retórica e da oratória, com a figura cimeira do Padre Francisco Mendonça, célebre sobretudo pelo seu viridarium. ${ }^{14}$

Desviando-me, porém, do que já é mais ou menos do domínio público, vou enveredar agora por sendas menos visitadas, dando a Luís da Cruz a companhia de Manuel Correia e de Justo Lípsio. Deste último, todos sabemos ser uma das figuras marcantes, se não a mais marcante, do humanismo europeu de finais do século XVI que irradiava na altura na região flamenga. $\mathrm{O}$ seu

${ }^{9}$ Sobre os escritos de Luís da Cruz, impressos e manuscritos, cf. relação apresentada em Luís da Cruz, Teatro, Tomo I: Sedecias, estabelecimento do texto latino, introdução, tradução, notas e comentário de Manuel José de Sousa Barbosa, Imprensa da Universidade de Coimbra, 2009, pp. $9-14$.

${ }^{10}$ Texto manuscrito em ARSI, Lus. 59, fls. 5-98. Como se conclui da leitura dos fls. 32r-33r, este Irmão Domingos João, um leigo coadjutor temporal, teve uma acção determinante naqueles dias de balbúrdia no Colégio das Artes, anteriores à memorável representação da tragédia Sedecias e coincidentes com a estadia de D. Sebastião em Coimbra, em finais de Outubro de 1570. Cf. Luís da Cruz, Teatro...cit. pp. 45-48.

${ }^{11}$ Nascido em Botão, no ano de 1596, entrou na Companhia de Jesus em 1610. Mais tarde ingressou nos Franciscanos e foi o célebre Frei Francisco de Santo Agostinho de Macedo, que em França e Itália espantou as gentes com o seu saber enciclopédico.

${ }^{12}$ Cf. Carlos Sommervogel, S. I., Bibliothèque de la Compagnie de Jésus, Bruxelles, 1890-1909, s. u. «Macedo, François », col. 245-246.

${ }^{13}$ João da Rocha compôs a écloga Marsyas (1616) e a tragicomédia Daniel Sapiens honestatus (1616); Afonso Mendes compôs a Tragicomédia São Paulino, Bispo de Nola (1604). Além do que, sobre estes nomes, vem referido em Claude-Henri Frèches, Le Théâtre neo-latin au Portugal (1550-1745), Paris, Librairie A. G. Nizet - Lisbonne, Bertrand, 1964, pp. 131, 434-447, 458465, cf. ainda Sebastião Tavares de Pinho, "O Colégio das Artes da Universidade de Coimbra, e a tradição clássica no início do século XVII”, Biblos, 68 (1992) 47-76.

${ }^{14}$ P. Francisco de Mendonça, Viridarium sacrae et profanae eruditionis. Lugduni, Jacob Cardon, 1632. Trata-se duma obra de concepção barroca, uma monumental recolha cujos conteúdos recolhidos de obras de autores profanos e sagrados surgem dispostos simbolicamente por diversas zonas dum jardim ou vergel (lat. uiridarium). 
percurso de vida é curioso: educado inicialmente pelos Jesuítas, viajou depois pelo Luteranismo e pelo Calvinismo, fase a que se associa uma presença marcante na Universidade de Leiden, acabando depois, já no final da vida (viria a falecer em 1606), por regressar à ortodoxia católica e ensinar na Universidade de Lovaina, cidade à qual, num gesto simbólico, doou o seu próprio coração. Ao contrário de Justo Lípsio, Manuel Correia é uma figura obscura, de que pouco se fala. No verbete que Barbosa Machado lhe dedica na sua Bibliotheca Lusitana, ficamos a saber que era natural de Elvas, que se licenciou em Direito Canónico ("em os Sagrados Canones"), que era "Examinador Sinodal do Arcebispado de Lisboa e Parocho da Igreja de S. Sebastião da Mouraria" e que "teve estreita amizade com o insigne Luis de Camoens a cuja instância ilustrou com eruditos Comentários o seu Poema dos Lusiadas". ${ }^{15}$ Das outras suas obras, terão ficado manuscritas os seus Princípios de Gramática e Cornélio Tácito traduzido em português. Barbosa Machado refere ainda o facto de, devido à sua "erudição historica e poetica" ter merecido "a correspondência de varoens famosos, entre os quais se distinguiu o célebre filólogo Justo Lípsio". Porém, sobre a sua correspondência inédita em que baseio este meu estudo, não surge qualquer referência.

Uma parte desta correspondência inédita encontra-se no códice da British Library Sloane 902, que contém a segunda centúria da correspondência de Manuel Correia, organizada pelo próprio, como se pode ver quer no título, quer na carta introdutória que se lhe segue, endereçada a Nuno Álvares de Portugal. ${ }^{16}$ Nessa carta introdutória, o autor solicita um parecer sobre a hipótese de mandar imprimir esta centúria de cartas. Manuel Correia alega nunca ter sido essa a sua intenção, mas que as insistências dos amigos acabaram por convencê-lo do interesse da publicação da sua correspondência, pelo que necessita da sua opinião. ${ }^{17}$ Conclui-se das suas palavras que já teria organizado, nos mesmos moldes, uma Centuria prima.

Nesta centena de cartas, distribuídas cronologicamente entre Julho de 1600 e Agosto de 1601, deparamos com uma série de nomes que remetem para vários quadrantes da alta sociedade de então. De destacar, além do já referido Nuno Álvares de Portugal, são os nomes dos Jesuítas Luís da Cruz e Álvaro Lobo, o de Diogo Paiva de Andrade, conhecido humanista autor das

\footnotetext{
${ }^{15}$ Estes comentários aos Lusíadas foram impressos duas vezes, uma primeira em 1613 e uma segunda em 1720 .

${ }^{16}$ Filho do $2^{\circ}$ Conde de Vimioso. Do partido Filipino. Foi presidente do Senado da Câmara de Lisboa e Governador sob o reinado de Filipe III.

${ }^{17}$ Ecce alteram epistularum centuriam, secundam scilicet. Mitto eam tibi, Nune generose, eadem prorsus lege, qua primam, ut legas, ac relegas; et lentissime uideas, an sit typis tradenda, ut clamat amicorum /2v/turba. Non id meum consilium, non ea fuit unquam mens (audiuisti ex me iam millies) sed flagitant amici, immo urgent. - British Library, Sloane 902, fl. 2r-2v.
} 
tragédias Eduardus e Ioannes Baptista e do poema épico Chauleida, entre outros escritos, ${ }^{18}$ o de Manuel de Sousa Coutinho, o futuro Frei Luís de Sousa, mas nesta altura bem arreigado na vida secular, ${ }^{19}$ e, por fim, para só me deter nos ilustres, o nome de um dos mais famosos músicos portugueses, de quem se diz que rivalizou com Palestrina e que morreu com a bonita idade de 103 anos. Refiro-me a Duarte Lobo, a favor de quem Manuel Correia intercede, mais de uma vez, nesta correspondência, em cartas para João Moreto, possivelmente apoiando a publicação das suas obras na imprensa Plantiniana. ${ }^{20}$

Só uma leitura exaustiva deste epistolário poderá dar conta de todos os episódios contidos nesta correspondência, cada um deles correspondendo a um núcleo de várias cartas, com os seus interlocutores desempenhando um papel específico. Não vos falo a partir dessa leitura exaustiva. Cheguei a este texto manuscrito apenas movido, inicialmente, pelo desejo de saber alguma coisa mais de Luís da Cruz, após ter observado que, na sumária referência que o Iter italicus ${ }^{21}$ apresenta deste códice da British Library, o nosso Jesuíta aparece aí em muito boa companhia. Justo Lípsio foi o nome que desde logo me chamou a atenção. Como se sabe, Lípsio surgia em finais do séc. XVI como a figura mais proeminente dum vigoroso movimento humanista que irradiava na altura nos Países Baixos. Esse humanismo flamengo reorientava de certo modo a leitura dos autores antigos privilegiando novos modelos, vistos como inspiradores de respostas mais fecundas para os novos tempos. $\mathrm{O}$ centro de gravidade dessa leitura deslocava-se dos autores da época de ouro da literatura latina (Cícero e Virgílio, sobretudo) para autores duma certa periferia, como Plauto, e outros ligados à literatura da época imperial, como Séneca e Tácito. As edições promovidas por Lípsio falam bem dos autores de leitura privilegiada por esta corrente humanista. ${ }^{22}$ À emergência de Tácito, por obra de Justo Lípsio, como o historiador da Antiguidade que melhor poderia inspirar a política de então, associou-se a preponderância dum estilo rebuscado e difícil onde pontuava o gosto pelo arcaísmo e pela erudição. Este epistolário constitui, neste aspecto,

${ }^{18}$ Sobrinho de Diogo Paiva de Andrade (1528-1575), teólogo ilustre, enviado ao Concílio de Trento por D. Sebastião.

${ }^{19}$ Acabara de ser nomeado para capitão-mor de Almada e estaria em vias de incendiar aí uma das suas casas, para impedir que nela se alojassem os governadores do reino, fugindo à peste que grassava, precisamente nesta altura, em Lisboa. É possível que o episódio histórico do incêndio da sua própria casa, em Almada, mereça referência numa das seis cartas que lhe são endereçadas nesta correspondência. $\mathrm{O}$ que se pode dizer é que o seu nome surge muito ventilado na correspondência entre Manuel Correia e Nuno Álvares de Portugal.

${ }^{20}$ Como se pode ler na Biblioteca Lusitana, a Arte da Musica de Duarte Lobo, editada em 1603 na tipografia acabada de referir, contém versos de Manuel Correia de elogio ao autor.

${ }^{21}$ P. O. Kristeller, LatinManuscript Books Before 1600: A List of the Printed Catalogues and Unpublished Inventories of Extant Collections. Munich, 1993.

${ }^{22}$ Séneca, Plínio-o-Moço, Tácito, Juvenal, são alguns dos nomes que mereceram os cuidados filológicos de Justo Lípsio. 
um testemunho da chegada do Lipsianismo também ao nosso país. Lípsio tinha aqui os seus admiradores, e Manuel Correia era um deles, como iremos ver, e tinha aqui também os seus críticos, como seria o caso de Luís da Cruz, em paralelo com o que se passaria na mesma altura nos sectores humanistas da Companhia de Jesus.

Da voga desta corrente lipsiana do humanismo dá conta Luís da Cruz no prefácio ao seu teatro que acabaria por ficar inédito, intitulado ao leitor erudito e benévolo, substituído pelo que surge na edição de Lyon, com um título ligeira mas significativamente modificado: Ao leitor benévolo e amigo. Este não inclui qualquer menção explícita a Lípsio e aos lipsianos, bem ao contrário daquele, todo ele assente na preocupação do dramaturgo de se defender contra eventuais críticas que lhe adviriam de determinados eruditos que o acusariam de não seguir as tendências mais em voga na altura, protagonizadas por Lípsio e pelos seus seguidores. Daí que este prefácio inédito, na sua forma epistolar, apresente um discurso bem estruturado em que, após um exórdio dedicado à importância do papel dos críticos na análise da boa literatura, o dramaturgo enuncia, no que se pode considerar a partitio, os principais pontos polémicos eventualmente suscitados pelo seu teatro, em cuja defesa se lança depois. ${ }^{23} \mathrm{E}$ sobretudo no que diz respeito ao estilo que a referência explícita ao lipsianismo em voga mais se faz notar. Após nos colocar perante a interpelação dos críticos que lhe perguntam pelos vestígios da expressão arcaica, cuja inexistência desvalorizaria imediatamente a obra aos olhos dos eruditos da actualidade e cujo cultivo grangearia ao seu autor não apenas autoridade mas também a amizade dos homens mais eruditos da Holanda, Luís da Cruz defende-se dizendo não ser forçoso que a sua obra rescenda a antiguidade. Chama em sua defesa Cícero, que afirma, em Orator 36, que

"No domínio da pintura uns deleitam-se com o que se apresenta grosseiro, descuidado, misterioso e opaco, enquanto outros com o que se mostra brilhante, risonho e luminoso, não havendo meio de exprimir por que normas ou fórmulas cada coisa se torna excelente no seu próprio género." ${ }^{24}$

Apesar de Lípsio e os Lipsianos procurarem imitar as rudezas do estilo arcaico e de lhes não negar mérito nisso, Luís da Cruz confessa optar pelo estilo harmonioso e agradável que usou na sua Paráfrase dos Salmos, e que lhe mereceu o elogio de Marco António Mureto, patente no parecer emitido previamente à edição da obra. Afirma Luís da Cruz:

${ }^{23}$ Cf. texto latino deste prefácio, acompanhado de tradução, em Manuel Barbosa, "Luís da Cruz e a poética...”, cit., pp. 384-405.

${ }^{24}$ In picturis alios horrida inculta, abdita et opaca, contra alios nitida laeta conlustrata delectant. Quid est quo praescriptum aliquod aut formulam exprimas, cum in suo quidque genere praestet. 
"Eu confesso ter seguido um tipo de escrita que, não sendo, quanto a mim, desprovido de energia, resulta musicalmente bem constituído. Por isso, tal como deixamos àqueles excelentes homens o hiato e também o encontro de vogais, com a desaprovação também de Marco Túlio, não é por isso que sentimos repugnância em relação a eles, mas confirmamo-los como dignos do seu mérito." ${ }^{25}$

Este prefácio foi escrito pelo menos após 1597, ano da edição da sua Interpretatio Poetica dos Salmos, aludida no prefácio, como acabamos de ver, e certamente depois de 26 de Julho de 1601, data da última carta desta centúria epistolar de Manuel Correia. A ausência de qualquer referência ao seu trabalho de revisão dos textos teatrais neste núcleo de correspondência assim nos faz pensar. Em todo o caso, a defesa do seu teatro contra eventuais reparos críticos advindos dos eruditos lipsianos será certamente reflexo do debate literário em curso, no qual a Companhia se erguia então na defesa do ideal ciceroniano de eloquência, contra a doutrina dos engenhosos aticistas e anti-ciceronianos, na linha, aliás, do que viria a ser testemunhado nas Prolusiones Academicae do Jesuíta Famiano Strada, obra editada em 1617. ${ }^{26}$

Mas regressemos à Centuria Secunda do epistolário de Manuel Correia. Envolvem-se nesta correspondência, como de certo modo já ficou sugerido acima, o que podemos considerar a elite do nosso humanismo naquela altura, gente socialmente bem colocada, amante da cultura literária grecolatina e que, nuns casos mais que noutros, faz avultar nos textos destas cartas, maioritariamente remetidas por Manuel Correia, mas não só, múltiplas marcas da leitura dos antigos. Luís da Cruz é, obviamente, um desses casos de escrita epistolar recheada de alusões a passos da literatura antiga, predominantemente latina, mas também grega. Este círculo de humanistas compraz-se em partilhar questões de erudição literária, lado a lado com outras questões emanadas da banalidade do quotidiano, mas umas e outras tratadas sempre num clima de afectuosa cordialidade que nos faz pensar em Plínio-o-Jovem como o principal modelo aqui subjacente. ${ }^{27}$ No que respeita a questões da vida quotidiana,

${ }^{25}$ Texto latino Ibid., p. 401.

${ }^{26}$ Famiani Stradae Prolusiones Academicae, Romae, apud Mascardum, 1617. Sobre o papel desta obra, cf. Marc Fumaroli, L'Âge de l'éloquence: Rhétorique et "res liraria de la Renaissance au seuil de lépoque classique, Paris, Albin Michel, 1994, pp. 190-202.

${ }^{27}$ A este estilo epistolar, convém referi-lo, não será alheia também uma propositada revisão final do autor, com retoques aqui e ali, mesmo em cartas que não fossem suas, tendo em conta a sua eventual publicação, o que constituía prática habitual dos humanistas. Assim terá feito Justo Lípsio, na preparação das suas centúrias epistolares. Cf. Iusti Lipsi Epistolae, pars I: 1564-1583. Curauerunt A. Gerlo - M. A. Nasnwelaerts - H. D. L. Vervliet. 1978, Paleis Der Academien Hertogsstraat: Brussel, p. 14. 
refira-se, por exemplo, o nascimento dum filho a D. Nuno Álvares de Portugal, facto que é celebrado por Manuel Correia com uma composição poética. ${ }^{28}$ A esta e outras composições de poesia episódica espera-se uma apreciação na carta de resposta. Ao mesmo Nuno Álvares de Portugal agradece Manuel Correia uma água que aquele lhe enviou e que resultou muito benéfica para os seus olhos. ${ }^{29}$ Aqui e além, nesta correspondência, pode o leitor surpreender-se com a menção de factos que terão alarmado a sociedade na altura, como o que vem referido na carta 78, ${ }^{30}$ dirigida a Luís da Cruz.

Passo a narrar. Já Manuel Correia acabara de dobrar a carta quando the chega a notícia dum caso espantoso de travesti na cidade de Lisboa, notícia que ele se apressa a incluir ainda na carta, como post scriptum. O caso era o seguinte: uma mulher ousara, três anos a fio, passear-se vestida de homem em plena cidade de Lisboa, em companhia de figuras respeitabilíssimas, usando o nome de Manuel de Sousa Coutinho e, nota interessante, frequentava os mosteiros, os ginásios e colóquios públicos (colloquia publica), levada por homens da alta sociedade, que Manuel Correia prefere silenciar por consideração para com as pessoas (bonestatis causa), e cometia, ao que dizem, actos abomináveis que se envergonha de referir (quae pudet referre). Este formoso e delicadinho adolescente (formosulus iste adolescentulus, et delicatulus) acabou por ser preso e entregue ao Juiz dos assuntos criminais, Gregório de Oliveira que, tal como o verdadeiro Manuel de Sousa Coutinho, é também aqui um dos correspondentes de Manuel Correia.

Mas, obviamente, é o aspecto da erudição literária que mais caracteriza e valoriza esta correspondência. Manuel Correia, por exemplo, eufórico com a correspondência encetada com Justo Lípsio, informa disso alguns dos seus amigos, enviando-lhes cópias das cartas e solicitando-lhes opiniões sobre o teor delas. ${ }^{31} \mathrm{~A}$ um tal D. Damião de Aguiar, destacado membro das cortes, há uma referência a Buchanan, de certo modo inesperada, dada a fama de herético que sobre ele corria. Não apurei todo o significado desta referência, lendo outras cartas do mesmo núcleo, ou seja, do que liga Manuel Correia a Damião de Aguiar. O texto latino, na tradução que lhe faço, dirá mais ou menos o seguinte:

Buchanan está presente apenas com as cartas dos amigos. Envio-tas para que vejas toda a importância que o mundo dá a um homem quase desconhecido nesta cidade. Desconbecido, digo, dos que desconbecem a virtude e o talento. ${ }^{32}$

\footnotetext{
${ }^{28}$ Carta 61: Cf. BL, Sloane 902, fl. 42r-v.

${ }^{29}$ Carta 80: Ibid. fl. 59-r-v.

${ }^{30}$ Ibid., fls. 57 r-59r.

${ }^{31}$ É o que sucede, por ex., na carta 39, endereçada a Luís da Cruz: “(...) Nunc Iusti Lipsii epistulas, alteram ad me, ad Nunum Mendozium alteram, discipulum olim nostrum, nunc Brusselae cum Alberto Principe commorantem, tibi mitto legendas; ut quid tibi uideatur Belga ille, respondeas." (Ibid. fl. 25v).

${ }^{32}$ Bucananus adest cum epistulis amicorum dumtaxat. Has mitto tibi, ut uideas quanti faciat orbis
} 
Mas outros nomes, neste caso de autores clássicos, atestam a erudição que perpassa esta correspondência, revelando a qualidade deste sodalício literário. Cícero, Virgílio, Boécio, Marcial, Horácio e outros afloram várias vezes no discurso, sublimando-o com um toque de autoridade. E não apenas autores latinos, mas também gregos, citados em grego, como aquela máxima do comediógrafo Filémon, preservada no florilégio de Estobeu:

\section{Assim é a vida do homem: alegramo-nos menos do que sofremos. ${ }^{33}$}

Para Manuel Correia, este convívio literário, este sodalicium, como o designa, representa o que ele tem de mais caro na vida. Lípsio e Luís da Cruz surgem aí como aqueles que, pela sua celebridade, mais o honram. Um conjunto referências disseminadas por esta correspondência assim o confirma. Eis algumas. Logo no início da segunda carta, endereçada a Frei Álvaro Leitão, Provincial da Ordem dos Pregadores, pode ler-se: Eis as cartas para ti. O mundo conhece Lipsio e Cruz; a nós, nem sequer o recanto mais pequeno da nossa cidade. ${ }^{34}$ A Nuno Mendonça, seu antigo aluno, actualmente a prestar serviço militar em Bruxelas como mestre de campo junto do Príncipe Alberto, fala sobre o dramaturgo jesuíta nos seguintes termos:

É o famoso Cruz, muito conceituado entre aqueles eruditos padres, de grande reputação. Editou recentemente uma obra, a Paráfrase aos salmos de David. Talvez já a tenhas lido. E prepara-se para uma outra, este varão erudito e muito meu amigo. Trocamos correspondência um com o outro. ${ }^{35}$

Mais à frente, na carta 60, exultante por tanto Lípsio como Luís da Cruz o honrarem respondendo às suas cartas, proclama, eufórico:

Sim, verdadeiramente sou um homem feliz, naquela zona fecunda dos sentimentos em que amamos. Com efeito, a quem aconteceu alguma vez tal convívio de amigos, tal amizade? Dum lado, Lípsio, o pélago das letras; do

hominem hac in urbe uix notus, ab illis dico, qui uirtutem nesciunt et ingenia. (Ibid. fl. 38v).

${ }^{33}$ Toiouto o bios anthropou, euphainometha ellaton, e lypoumetha Ibid. fl. 25v. Neste fragmento de Filémon inclui-se o vocativo gyne, após anthropou aqui omitido. Cf. Poetae Comici Graeci, edd. R. Kassel et C. Austin, Berlim, Walter de Gruyter, 1989, vol. VII, p. 301. Filémon, que viveu entre 368/69 e 267/63 a. C. integra-se na chamada "comédia nova". Estobeu, escritor grego do séc. $V$, autor dum importante florilégio de máximas, que viria a merecer tradução latina pela primeira vez no séc. XVI, pelo suíço Conrad Gesner.

${ }^{34}$ En epistulas tibi. Lipsium, et Crucium nouit orbis, nos ne minimus quidem urbis nostrae angulus. (Cf. BL, Sloane 902, fl. 2r).

${ }^{35}$ Est Crucius ille inter illos eruditos patres magni nominis. Recens nunc opus edidit in Dauidicos Psalmos Paraphrasim, legisti iam fortasse, ad aliamque accingitur uir eruditus, et amantissimus mei. Scribimus inuicem. (Ibid. fl. 22v). 
outro, Cruz, produzido pelas Musas; depois estão outros seiscentos, todos excelentes, cada um à sua maneira. ${ }^{36}$

E prossegue dizendo que não trocaria uma situação destas nem pelo ouro, nem pelo auge da fortuna, nem pelo ceptro duradouro do poder nem pela tiara pontifícia. $\mathrm{Na}$ carta 78 , ainda sobre esta constelação de eruditos afirma: Realmente, nada há de mais sério para mim do que este sodalício de amigos, no qual eu construo de preferência os livros. ${ }^{37}$

No que diz respeito à correspondência com Justo Lípsio, foi Manuel Correia a tomar a iniciativa de lhe escrever, como o próprio revela, após muito tempo de hesitação, inibido pela suprema autoridade da pessoa que admirava à distância. ${ }^{38} \mathrm{O}$ pretexto facilitador desta tomada de resolução foram duas cartas que lhe chegaram de Nuno Mendonça: uma remetida por este, e outra de Justo Lípsio para Nuno Mendonça. Da carta de Manuel Correia para Justo Lípsio passo a ler o seguinte excerto, por si só revelador do entusiasmo e do interesse que a personalidade de Justo Lípsio despertava em Manuel Correia e no seu círculo de amigos:

Felicito-te pois, varão eruditíssimo, em nome dos Portugueses, pela índole notabilíssima do teu espírito, pela tua enorme generosidade para com todo o mundo e sobretudo para com esta nossa parcelazinha da remota Hispânia que tanto se apascenta dos teus livros, tanto os aprecia e de certo modo deles se alimenta e vive, que julga que as tuas obras apenas em atenção a ela foram elucubradas, apenas em atenção a ela vieram à luz do dia. E a tal ponto estão os Lusitanos afeiçoados ao nome de Lípsio que tenho a suspeita de que, alterando a sua designação de origem, se poderiam chamar Lipsianos. ${ }^{39}$

$\mathrm{Na}$ carta de resposta, enviada através do já referido Nuno Mendonça, Lípsio agradece a Manuel Correia todas as cortesias contidas na carta deste, confessa não estar no pedestal em que ele o coloca mas perdoa-lhe este erro de apreciação, cometido por simpatia. Elogia, além disso, a gente lusa, muito célebre não apenas nas armas mas também nas letras. E no que se refere a

${ }^{36}$ Nam ego felix homo sum, felici illa dico animorum parte qua amamus. Cui enim umquam tale contigit amicorum sodalitium, talis amor? Hinc Lipsius literarum pelagus, illinc Crucius a Musis factus, inde sexcenti adsunt alii, suo quisque modo, praecellentes. (Ibid. fl. 41r).

${ }^{37}$ Nibil enim mibi magis serium, quam amicorum sodalitium, in quo potissimum libros constituo. (Ibid. fl. 58r).

${ }^{38}$ Huic operi millies iam manus apposuissem (...) nisi - quod certius est - binc ingenii nostri tenuitas, illinc Lipsii deterreret auctoritas (Iusti Lipsii Epistolae, pars XIII: 1600, curauit Jan Papy. Paleis Der Academiën - Hertogsstraat 1, Brussel, 2000, p. 166). Esta carta, com a data de 1 de Junho de 1600, não integra a Centuria II de Manuel Correia. Possivelmente incluir-se-ia na Centuria I, cujo paradeiro se desconhece.

${ }^{39}$ Gratulor igitur tibi, uir doctissime, Lusitanorum nomine praeclarissimam animi tui indolem, largissimam in totum terrarum orbem munificientiam maximeque in hanc nostram extremae Hispaniae regiunculam, quae ita libris tuis pascitur, it a fruitur et certo quodam modo alitur et uiuit, ut sibi tantum elucubrata, sibi tantum edita fuisse opera tua existimet. Adeoque in Lipsii nomen affecti sunt Lusitani, ut mibi suspicio sit fore aliquando ut originis nomine immutato Lipsiani appellentur. (Ibid., p. 167). 
estas, os frutos que elas têm dado, duma forma que não se vê em nenhum outro rincão de Espanha, mostram que os Portugueses conservam bem vivo o fogo da cultura literária primeiramente aceso em suas terras por Sertório. Fala ainda do gosto que teria em visitar a Lusitânia e conhecer as suas gentes, se para tal houvesse condições, o que não sucede devido à guerra. Termina com uma série de expressões afectuosas que Barbosa Machado deixou registadas na notícia que lhe consagra: Te, mi Correae, uideam, pectori applicer, collo adstringar, atque ipsa hac cogitatione liquesco, et moueor: quid si re frui detur? (Pudesse eu ver-te, meu caro Correia, abraçar-te, agarrar-me ao teu pescoço, e só com este pensamento desvaneço-me e deixo-me comover. E se nos for dado desfrutar deste acontecimento?). ${ }^{40}$

Nesta Centuria II de Manuel Correia, na carta 91, está registado um segundo momento de troca de correspondência. Lípsio informa Manuel Correia que acaba de editar a Centuria III das suas cartas, de que lhe enviará um exemplar. Termina a sua breve carta com referências ao seu estado de saúde (sente-se a enfraquecer: languor) e ao descanso eterno, cuja iminência já pressente e para o qual se prepara. ${ }^{41}$ A resposta de Correia (carta 99), em cujo comentário não me vou alongar, glosa o topos da orfandade pela perda dum amigo, tece considerações sobre a vida eterna e termina dizendo da sua muita ansiedade por receber a referida centúria de cartas acabada de editar. ${ }^{42}$

\section{Manuel Correia e Luís da Cruz}

A correspondência entre estas duas figuras vem testemunhada nesta centúria em sete cartas, quatro de Manuel Correia e três de Luís da Cruz e, como o sugere a primeira delas, de Manuel Correia, dá continuidade a uma prática anterior, testemunhada certamente na Centuria I, e promete continuidade, o que nos remeteria para uma eventual Centuria III, cuja existência ignoramos de todo. Como já referi, Barbosa Machado, na sua Bibliotheca Lusitana, não faz menção de qualquer centúria epistolar que tenha ficado manuscrita.

Não pretendo fornecer aqui uma relação exaustiva das questões ventiladas na correspondência entre estas duas figuras. Uma série de temas perpassam nestas sete cartas, articulando-as de forma interessante. A relação que aqui vou dar, respeitando a sucessão cronológica das cartas, não é exaustiva. A narração que segue, algumas vezes em estilo indirecto, articula uma história, através dos seguintes pontos, assim enunciados: a cegueira de Manuel Correia; a emenda de Marcial ou os olhos que o deverão ler; Justo Lípsio ou a erva curativa que devolve os mortos à vida.

\footnotetext{
${ }^{40}$ Cf. Ibid. pp. 275-277.

${ }^{41}$ BL, Sloane 902, fl. 65r-v.

${ }^{42}$ Cf. Ibid., Als. 89v-90v
} 


\section{$1^{\text {a }}$ carta (de 14 de Outubro de 1600): $:^{43}$}

Relata Manuel Correia a Luís da Cruz que a 3 de Setembro de 1600 saíra de casa, de manhãzinha, para assistir ao auto de fé que teria lugar nesse dia no átrio da Inquisição. Fizera-o a pedido dos amigos. Sucedeu porém que, olhando para os que saíam cobertos com as insígnias da heresia, reconheceu alguns que vira ainda na véspera passeando-se com roupas de seda e fazendo-se transportar em cavalos e mulas. Estupefacto e indignado com aquilo, regressou a casa e, na doçura da solidão, sozinho apenas para si, arrumou a escrivaninha e lançou-se ao trabalho que tinha entre mãos, ou seja, comentar Marcial. E, com uma grande disponibilidade mental que se traduziu em eficiência, deu conta só nesse dia de 60 epigramas. Porém, no fim, sentiu os olhos escurecerem, ficarem enevoados e como que cobertos por um véu. Assaltou-o o pânico. Recorreu a Deus, recorreu aos amigos, recorreu a médicos e cirurgiões. Cada um aconselhava uma coisa e ele pouco fazia, receoso que lhe acontecesse o que a outros acontecera com os excessos da cura: a extinção da luz vital. Fora esta a razão por que deixara de lhe escrever. Termina a carta pedindo a Luís da Cruz que ponha os seus amigos da Companhia a rezar por ele.

\section{$2^{\text {a }}$ carta (de 13 de Dezembro do mesmo ano): ${ }^{44}$}

Responde Luís da Cruz que se encontrava acamado quando lhe chegou a carta do amigo. Pensava encontrar nela um lenitivo para os seus próprios males mas, ao inteirar-se do conteúdo, ficou desolado e, para não lhe causar igualmente desolação, prescindiu de falar dos males que o haviam mantido acamado e optou apenas por consolar o amigo. A cegueira, reconhece Luís da Cruz, é de facto um mal bem cruel para os literatos, dado o uso que estes fazem dos olhos, mas há forma de a suportar. Que ele repare em Dídimo de Alexandria, o cego, tão forte em sabedoria e santidade que Jerónimo não hesitou em navegar até Alexandria para, junto dele, se aconselhar sobre questões que o seu espírito perspicaz não conseguia resolver. Neste mundo, todos representamos de certo modo uma tragédia. Manuel Correia poderá sentir-se um Édipo, mas não terá necessariamente de se mostrar um Róscio, exagerando em choros e lamentações. Pior cegueira do que a dele era a dos que Manuel Correia vira no auto de fé. A dele apenas lhe retardava a explicação de Marcial. Acha bem que pense dar brilho (lucem dare) a este poeta, de forma a que a juventude possa ler o que ele conserva de agudo e de erudito, mas só

\footnotetext{
${ }^{43}$ Carta 19 da Centuria II de Manuel Correia. Alertamos para que nem sempre a datação das cartas se harmoniza com a sucessão dos factos nelas relatados. Em apêndice, poderá apreciar-se, na íntegra, o texto latino das cartas trocadas entre Manuel Correia e Luís da Cruz.

${ }^{44}$ Carta 40 da Centuria II de Manuel Correia.
} 
depois de, com a foice da irrepreensível virtude, ter afastado para bem longe a perversidade e a luxúria. $\mathrm{O}$ que lhe aconteceu à vista talvez ensine que Marcial deverá ser lido com os olhos vendados, porque quem se ocupar dele com os olhos abertos, ficará contaminado pelo veneno da impudicícia. Boa sorte para este trabalho é o que lhe deseja, mas também contenção. Sessenta epigramas num dia apenas é demasiado; configura um caso de avidez nos estudos. Foi esta avidez que deu azo a esse obscurecimento imperceptível da visão. Que se lembre do passo da Eneida "Maturate fugam":45 a fuga tem rapidez mas também tem de ser refreada; ou então do velho ditado grego speude bradews, em latim Festina lente. ${ }^{46} \mathrm{E}$ quanto aos médicos, nada a fazer. Não nos curam sem de algum modo nos prejudicarem. Já Marcial sugere esta ambiguidade da medicina: Cem mãos me tocaram, geladas do Aquilão. Não tinha febre, Póstumo; agora tenho. ${ }^{47}$ Portanto, há que consultar os médicos. Que prepare o dinheiro. E Luís da Cruz fecha esta carta com um prémio de consolação (corollarium): dispõe-se a contribuir para o prazer e a honra do seu amigo escrevendo qualquer coisa, mas que seja este a apresentar o assunto, a provocá-lo.

\section{Resposta de Manuel Correia (de 5 de Janeiro de 1601): ${ }^{48}$}

No que à cegueira diz respeito, Manuel Correia está convencido de que caminha a passos largos para a perda de visão, e logo numa altura em que tanto precisava da vista para a explicação de Marcial. De Dídimo de Alexandria quer a literatura esmerada, mas quanto à cegueira que a tome quem quiser. Sobre Marcial, parece sossegar Luís da Cruz dizendo que acrescenta Marcial na parte em que ele é elogiável, digno de ser imitado. O seu esforço orienta-se no sentido de publicar este poeta muito erudito, purificado de todo o veneno, limpo de qualquer inconveniente. Termina referindo-lhe o envio de duas cartas de Justo Lípsio, para que as leia e dê a sua opinião sobre o homem. Eis matéria para a resposta, ou melhor, para o prémio de consolação prometido.

\section{Resposta de Luís da Cruz (em carta de 15 de Dezembro de 1600): ${ }^{49}$}

Se Dídimo não lhe agrada de todo, que se vire para Gregório que, pelo muito que fez apesar da sua bem frágil saúde, mereceu o cognome de Magno. Que peça a Deus constância de carácter e sobretudo paciência. Que a vista

\footnotetext{
${ }^{45}$ Virg., Ae. I, 141.

${ }^{46} \mathrm{E}$, em português, talvez "Devagar se vai ao longe" ou, de forma inversa, "Quanto mais depressa mais devagar”. Quanto ao provérbio grego, segundo Suetónio (August. 25) Augusto recorria a ele muito frequentemente, quer falando quer escrevendo.

${ }^{47}$ Cf. Marcial V, 9, 41, onde não surge Postume, mas Symmache. A alteração efectuada por Luís da Cruz esconde certamente motivação irónica.

${ }^{48}$ Carta 39 da Centuria II de Manuel Correia.

${ }^{49}$ Carta 59 da Centuria Secunda de Manuel Correia.
} 
lhe seja restituída, é o que lhe deseja, e ainda, já que recusa ser Dídimo, que supere em visão os linces, a bem do trabalho que tem em mãos. Mercê desse esforço, os Portugueses terão um português que fará com que não seja forçoso fazer vir de províncias estrangeiras quem explique Marcial, elegante mas obscuro. Que também ele, Luís da Cruz, de saúde igualmente frágil, todos os dias dá aulas e interpreta Daniel, ${ }^{50}$ além de fazer ainda frequentes pregações. Quanto a Lípsio, leu as cartas e confessa-se encantado com o facto de o seu amigo se corresponder com um varão tão erudito. E quanto à ideia de este visitar Portugal, será melhor dizer-lhe que não venha, ainda que possa. Viria encontrar a Lusitânia, não no seu apogeu, como era habitual, mas coberta e inutilizada pela desgraça da peste. Prefere saber que ele sofre na Bélgica a vêlo entristecer-se no meio da nossa desgraça. Quanto ao que pensa do homem, compôs o seguinte poema em hendecassílabos falécios: ${ }^{51}$

\section{Para Manuel Correia, sobre Justo Lípsio:}

Tendo tu há pouco solicitado ao teu amigo Cruz

Que elogio seria habitual dar a Lípsio,

Respondeu ele que Lípsio lhe parecia

A erva de Creta de folhas medicinais

Nascida para devolver a saúde aos feridos.

Estendiam-se nas encruzilhadas os homens de outrora

De cujas feridas todos se condoíam

E contudo os cirurgiões que, com mão Peónia, as trataram

Nada conseguiram com seus esforços.

Mas quando a velha doença experimentou

O sabor e o suco deste dictamno,

Fugiu de tal modo, Cura sagrada, que era

Dos que ocupavam as entradas

Como se tivessem fugido

Ao peso da passagem do tempo.

Que elogio farei a Justo? Oh! Do cimo do Ida

Rosa colhida no monte Dicte, vive!

Ao tocarem-te, os mortos regressarão à vida.

\footnotetext{
${ }^{50}$ Estaria Luís da Cruz a desenvolver uma paráfrase poética ao Livro de Samuel, à semelhança do que já fizera com os 150 Salmos da Bíblia. Esta informação condiz com um trecho duma carta de Manuel Correia a Nuno Mendonça, onde o mesmo é sugerido: Recens nunc opus edidit in Dauidicos Psalmos Paraphrasim, legisti iam fortasse, ad aliamque accingitur uir eruditus, et amantissimus mei. (Tradução: Editou recentemente a Paráfrase aos Salmos de David, talvez já tenhas lido, e prepara-se para outra, este varão erudito e muito meu amigo."). Cf. BL, Sloane 902, fl. 22v. O sublinhado é nosso.

${ }^{51}$ Como facilmente poderá verificar-se, o poema inspira-se no passo do livro XII da Eneida em que Vénus socorre, com o dictamno do Ida, Eneias ferido com uma seta, quando os médicos, com seus cuidados, não the podiam valer. Cf. texto latino do poema em "Apêndice", carta 59.
} 


\section{Resposta de Manuel Correia (em carta não datada): ${ }^{52}$}

Confessa-se exultante, felicíssimo com o círculo de amigos em que está integrado. A última carta de Luís da Cruz reconfortou-o e animou-o para trabalhos maiores, superiores às suas forças. Vai enviar Marcial para a fornalha, para que se estabeleça o mais rápido possível. E talvez a Marcial acrescente outro ou outros. Mas por agora, que o seu amigo o escute recitando versos a favor de Lípsio. ${ }^{53}$

Bem gostaria eu que o belga meu amigo

Teus hendecassílabos tivesse à mão!

Com que rosto os leria! Meus Deus, quantos abraços

Lhes daria, quantos beijos! Seriam mais

Do que os evocados por Catulo.

Mas, maldição! Aloja-se ele noutro mundo

Separado, bem longe. Portanto, agora, em vez do amigo fiel

Cobrirei de beijos estes números

Sem qualquer número. Meus amores

Direi, e ternura: e enquanto o caminho se vos fecha

Guardar-vos-ei alegre em meu alegre coração.

E agora a ti, Luís, brilho das Irmãs

Que velam superiores no meio do firmamento

Em nome da vontade de Justo Lípsio

Chamo-te a ti, a teus companheiros e amigos:

Concluo uma aliança perene de amizade.

Eis que Lípsio estende com prazer a sua dextra;

Vós as vossas estendeis, julgo que com prazer.

Ó coisa bem feita! Oh! Coisa maravilhosa!

Pessoas muito eruditas que estais vivas

Vistes coro mais erudito?

$$
\text { oOo }
$$

\section{Conclusão:}

Embora ainda faltassem mais duas cartas deste núcleo de correspondência entre Manuel Correia e Luís da Cruz, vou concluir. Tentei, com a apresentação desta desconhecida Centuria Secunda do epistolário de Manuel Correia, quebrar

${ }^{52}$ Carta 60 da Centuria Secunda de Manuel Correia.

${ }^{53}$ Os versos seguintes são propositadamente uma imitação de Catulo, perfeitamente reconhecível pelas alusões aos carmina 3 e 5 . 
um pouco a impressão de monotonia que, penso, se poderá ter do aspecto do humanismo português no dealbar do séc. XVII. Afinal, esquadrinhando melhor o aspecto desse humanismo, com a ajuda destas, quase todas, ignoradas cartas, vemos mais caminhos do que os que conduziam daqui apenas para Roma e para o Colégio Romano. Havia igualmente os que conduziam à Flandres, donde alguns esperavam avidamente que chegassem os frutos desse expoente de humanismo erudito que foi Justo Lípsio. Neste debate de ideias e partilhas de experiências literárias não se movimentavam apenas clérigos, fossem eles Jesuítas ou não, mas igualmente leigos, varões nobres, detentores de altos cargos políticos. E neste tempo de feroz inquisição, ainda havia quem ousasse, parece, chamar a debate nestas trocas de correspondência, a figura de Buchanan, o príncipe dos poetas, mas herético.

oOo 


\section{Apêndice}

\section{Epistularum Centuria secunda}

(BL, sloane 902)

\section{Correspondência entre Manuel Correia e Luís da Cruz}

[carta 19: Ibid. fls. 12r-13r]

Ludouico Crucio in Societate Iesu sacrarum literarum doctori S. D. 19

Quod ad litteras tuas eruditissimas insuper et amicissimas hactenus non responderim, non fecit Cruci Doctissime aut negligentia, aut tui obliuio, sed subita quaedam et repentina oculorum caligatio. Quod malum quam sit crudele, quam metuendum, nouit optime qui patitur: ego sane in summo sum squallore, in summa animi acerbitate, et metu. Vt autem infelicis casus ortum teneas, et humanae condicionis instabilem sortem, pauca haec perlege. III Non[is] Septembris, quo die celeberrimus ille fidei nostrae actus agebatur, amicorum aliquot rogatu inquisitionis atrium primo mane adii uisurus pertinacis et obstinatae mentis homines illos. Vt exeuntes uidi perfidiae amictos insignibus, quosdamque agnoui, quos antea deambulantes conspexeram sericis indutos, equis, mulisque uehentes, domum redii diram gentis barbariem admiratus, et ceruicem durissimam. Domi igitur $/ 12 \mathrm{v} /$ actus beneficio mihi uni uacans (molestos namque spectaculum abduxerat) et solitudinis captus dulcedine ad consuetum pabulum procurri, libros aperui, aptaui calamum, atramentarium composui, cogitationem denique hac occasione audaciorem multo feci, et liberiorem. Vtque rem omnem penitus intelligas (Martiali enim plenos adstruo commentarios) illa die sexaginta epigrammatis plenam apposui manum. Hoc duro penso cum defessos oculos animi gratia in uaria coniicerem, caligare eos sensi, et obnubi. Quo factum est, ut quam laetitiam legendo perceperam, et scribendo, parum uidendo tristissimus exuerem, in magnamque aegritudinem, ac maerorem conuerterem. Ad Deum primum excors accurri, amicos accersiui, medicos et chyrurgos consului, ut si possem tanti mali principiis saltem obsistere. Multi multa monent, ego pauca, uel nulla potius operor, ne forte quod mille aliis, mihi etiam curatione contingat uitalis lucis extinctio. Quocirca exteriores opes negligo, interiores dumtaxat, ut tutiores amplector: nimiis namque capitis humoribus malum istud et conflari, et augeri compertissimum habent quotquot de eo medice loquuntur. Quos quidem ego, etsi /13r/ rei medicae parum peritus, in incude tamen positus, et meo magno periculo sapiens, ausim asserere, ex assidua lectione, et scriptione profluere; nulla enim re magis aluntur, nulla magis fouentur. Medicis igitur potionibus res agitur, et catapotiis, et aliis quamplurimis, quae commemorare 
et tibi taedio et mihi sit dolori maximo, sola enim mentione distorqueor. Haec causa fuit, Cruci doctissime, intermissionis litterarum. Quis enim otio indulgeat in tanto negotio? Quis animi res agat in tanta animi perturbatione? Illud igitur te oro obsecroque: ut qui in Iesu Societate degis, socios tuos adeas, roges, cogasque Deum deprecari pro amico qui quamuis in amicitiae foedere non adeo est uetus, nulli tamen ueterum in fide et amore concedat. De epistula tua hoc unum: non tanti facit India lapillos, quanti ego epistulam tuam; quod si plures dederis, pluris faciam, tum quod plures, tum quod plus mihi dabunt et uoluptatis, et honoris. Vale. Olisipone XIX Kalend. Nouemb 1600.

[carta 39: Ibid. fls. 25r-26r]

Ludouico Crucio e Societate Iesu S. D. 39

Quo tu animo nostram legisti epistulam, eodem prorsus ego et tuam, beneuolo scilicet, et amico. Quid enim epistula tua in uerbis suauius, quid in consiliis utilius? Itaque eam libentissime perlegi, ac felicem sortem mihi primo gratulatus, multa deinde bona precatus sum Alvaro Lupo, uiro doctissimo, et amantissimo mei, cum talem mihi amicum conciliarit, qui et uirtute excellat, et doctrina. Atqui semper laetitiae comes dolor subsequitur; utque ille alter ait: 125v/ Toiouto o bios anthropou, euphainometha ellaton e lupoumetha: talis uita est hominis, laetamur minus quam dolemus. ${ }^{54}$ Quae enim epistula me in principio uera imbuerat laetitia, non multis post uersibus maerore accumulauit, dum tuam commemorat ualetudinem. Hac ego lecta ita dolui, ut oculorum dudum me conflictans dolor (solet hoc acerbiorum aduentu contingere) e mente nobis protinus abierit tuo plane concedens ut grauiori, ut acrius pungenti. Aegrotas, Cruci doctissime, malum quidem, malum magnum: sed corpore tamen aegrotas, non animo, non optima illa parte, quae ad animum ducit. Vides, uides: bonos illos affaris amicos, qui nobis numquam maerorem, uoluptatem afferunt semper. Et nos festino gradu ad caecitatem properamus carituri et amicis, et caelesti illa aura, qua fruimur, qua uiuimus. Didymus, ais, Alexandrinus caecus fuit, magni uir nominis, multae et politissimae literaturae. Hanc ego mihi uellem, caecitatem sibi capiat, qui uoluerit. At nunc mihi, si quando, oculi erant opus; habebam namque in incude magna fortasse (scies aliquando) ac feriatis aliquot horis Martialem addebam amicorum rogatu, qua tamen parte laudabilem, qua imitandum. Enitebarque ut publicaretur eruditissimus uates, omni purgatus ueneno, omni exutus crimine: iamque iampridem suadente Lupo nostro, nec /26r/ reluctantibus nobis, nuncque auctoritate tua omnibus uelis annuentibus. Damnamus Martialem impudicitiae, laudamus tersae latinitatis, et qui suo genere concedat paucis. Nosti uatem, tu eum Coryphaeum appelas. Nec mireris, si sexaginta mihi epigramata una dicam die elaborata; sexagies

\footnotetext{
${ }^{54}$ Talis uita...dolemus] na margem.
} 
elaborabo sexaginta. Nihil mutuum petimus, domi sunt omnia: calx, lapides, operae et operarum Magister, qui nouit optime architectari. De his tamen alias. Nunc Iusti Lipsii epistulas, alteram ad me, ad Nunum Mendozium alteram, discipulum olim nostrum, nunc Brusselae cum Alberto Principe commorantem, tibi mitto legendas; ut quid tibi uideatur Belga ille, respondeas. En nunc ad rescribendum materiam. Alias suggeret tempus. Quod si aliqua contigerit tuae uoluntatis, tui obsequii, haec mihi multo gratior, multo felicior existimabitur. Olisip Nonis Ianuariis 1601.

[carta 40: Ibid. fls.26r-28r]

Ludouicus Crucius Emmanueli Correae S. D. 40

Cum tuae litterae, mi Emmanuel, Conimbricam peruenerunt, lectulo affixus aegritudine iacebam. Quae ea sit, quam molesta, et diuturna, de Lupo nostro aliquando fortasse audiuisti. Cum uero traditae fuerunt, et intellexi esse tuas, respiraui. Leuamentum /26v/ aliquod contra dolores ab optimo amico (eum te quidem profiteor) allatum opinabar. Sed cum coepi legere, et intellexi quid calamitatis paterere ingemui. Quid ergo respondebo? Angorem mihi denuo peperere illae tuae litterae; in quo hoc boni, quod dolendo tibi, mihique satisfeci. Et ne apud te eadem sit uicissitudo, de me aegroto nihil. Vbi primum potui, ad scribendum preparaui. Accipe quales, quales istae tuae esse potuerunt. Age tua aegritudo non sit sine expectatione rerum meliorum. Valebis quam citissime. Et forte ea caligo ab oculis iam abscessit. Amplificabas id malum, credo, cuiusmodi sane fuit. Literatis, qui legendo, commentandoque pascuntur, non modo ea est grauis aegrotatio, sed animi acerba aegrimonia. Ceterum quo pacto sit sustinenda, non ignoras. Et tibi non erat gratia leuandi mali ad eos confugiendum, qui narrantur in fabulis fortasse data opera caecitatem asciuisse. Habebas exempla nostrorum, Didymi scilicet Alexandrini, qui quamquam oculis careret, non propterea infelicem se rebatur. Et doctrina ac sanctitate ita pollebat, ut Hieronymus non dubitaret Alexandriam nauigare, ut caecum adiret; atque ipsum aliqua percontaretur, quae sciebat mentis lumine abundare, ad ea illustranda, quae perspicax ingenio Hieronymus non uidebat. /27r/ Commemorabas eum locum, qui est amplissimus ad dicendum de instabili sorte rerum humanarum. Sic est. Ad hanc tragoediam nobilitandam omnes ita nati sumus, ut non modo iubeamur spectatores esse, sed etiam actores. Quot Oedipos in hanc orchestram quotidie det ista condicio, uides, mi Emmanuel, in quorum numero si te sors collocauit, non erit meum postulare ut lamentatione et in luctu te Roscium ostendas memorabilem; sed illum Didymum, cuius ante coepi meminisse. Redieras ab spectaculo illorum, quorum merito caecitatem detestabare. Tuam caligationem gratare tibi leuiorem, quae non eripuit mentem, qua te ualere scio, sed paulum a Martiali explicando retardauit. Et tu lucem dare illi homini putabas? Para. Agitantem ista non retardabo. Incidit ille 
in eum, ut spero, qui improbitatem, luxuriamque coercendo falce castissimae pudicitiae, quicquid in eo est acuti et eruditi dabit adolescentiae. Quaeque sit tractanda modeste, alios tua doctrina, tua uirtus, tua experientia diuturna, tua dignitas et sanctitas sacerdotii canique docuerint. Et fortasse docuisti tuo casu caecis oculis illum epigrammaton coryphaeum esse perlegendum, quem qui apertis tractarint, haurient, opinor, impudicitiae uenenum. Blandiri nescio, optime Emmanuel, serio cum amicis disserere candidi ingenii esse nosti. Sic te $/ 27 \mathrm{v} /$ opto bonas horas apud istum collocare, ut ex tuo colloquio prodeat non nequissimus, et tandem aliquanto prudentior loquatur seque ad eum diuertisse uideat, a quo didicerit morum fauere probitati. Sed sexaginta uno die epigrammata? Tam ardens es et uehemens! Legendo illa tamen fatigassent; quid quaeso commentando? Intemperiem istam me sine accusare. Pertulisses qui auiditate deuorando totidem patinas liguriret? Et non uides hanc esse in studiis auiditatem? Quid si inde, ut tu ipse non diffiteris, ista caligatio obrepsit? In posterum quid Emmanuel? Incolumitate restituta abibit metus aegritudinis? In altera sexaginta te armabis, ut una die dicare tot Antaeos Hercules in terram deiecisse, quot epigrammata confeceris interpretando? Mandabis obliuioni illud, quod est apud optimum poetam: maturate fugam? ${ }^{55}$ Fuga habet celeritatem, sed quam eam coerceat illud mature imperatum agnoscis. Quod igitur inde notum speude bradews tibi dictum puta. De medicis, quos allegabas, quid attinet disputare? De singulis si quis diceret:

quod si non aliqua nocuisset, mortuus esset, ${ }^{56}$

inuidiose loqueretur. Atqui a medicina speramus. Aegris ex ea disciplina promittitur ualetudo. Ambiguam uocem uides, et apud tuum Martialem est: centum tetigere manus - non habui febrim, Posthume, nunc habeo. ${ }^{57}$

Quid agendum? Accersendi sunt, et consulendi. Illi potiones inculcabunt, aurum para. Quantum boni ferent? Recte si non peperint nosemata. Illud est unicum perfugium, quod apud tuos est in extrema cura: deprecandum /28r/ Deum, Diuosque caelites, quos spero tibi bene facturum. Nosti hoc loquendi genus. Hanc aram imam, praesidio, salutique futurum satisfeci respondendo. Sit istud corollarium officii erga te. Nunc utcumque ualeo ad illa tua quae honestissimis nominibus appellas uoluptatem et honorem fauente Deo ualiturus. Si quid ego adiuto curamue leuasso scribendo, cur non faciam? Scribam, materiam praebe, prouoca, exilientem spectabis, nec ut exeam in hanc aciem cunctatior, ingenium detinebit Fabianum. Quod arbitrere hunc Lipsium ad tuum honorem pertinere, tribuo uirtuti tuae. Sed si est inde aliquid ornamenti, quantum ex me erit euadet meus Emmanuel Correa ornatissimus.

\footnotetext{
${ }^{55}$ Virg., Ae. I, 141.

${ }^{56}$ Cf. Virg. B. III, 15

${ }^{57}$ Cf. Mart. V, 9
} 
Appellas te amicissimum, amplector, dabo operam, ne queri possis aliquando te deceptum; et uideo quantum in meam fidem recipio. Parem exibere animum tuo, non arbitror esse leue. Conimbricae XIII Decemb[ris] 1600. Haec aegra manu scripta boni consule.

[carta 59: Ibid. fls. 38v-40v]

Ludouicus Crucius e Societate Iesu Emmanueli Correae S. D. 59

Beneuolentia et communio quaedam studiorum, mi Emmanuel, effecerunt, ut peramanter nostra legeres, quod etiam in tua epistula perlegenda me praestitisse /39r/ confiteor. Legi saepius legamque libenter, quoties uacauerit, et putaris amicum, quem esse uoluisti recreandum. Aegritudinem qua me scripsi detineri, non ideo commemoraui, quod eam dolori esse uoluissem, sed ut tuam quoquo modo leuarem calamitatem; ne tu te unum salute afflicta existimares, propterea ab scribendo et commentando cessaturum. Nam nos etsi cruciamur, animum tamen erigimus, et parte superiori contendente damus operam ne doloribus oppressi succumbamus. Quod si Didymus non placet, quem ad minuendum id malum, quo nuper laborabas, afferebam? Mihi, tibique Gregorius in mentem ueniat, cui non obstitit iniquissima ualetudo quominus agendo et scribendo Magni cognomen unus assequeretur. Quam ob rem uale ac graecus ille tuus. Deiecti animi eam sententiam ambo arbitremur. Etsi multa uitam incommoda circumueniant mens accuratiori studio Christianae sapientiae ea mitigare lenireque contendat. Quare id precor, optime ornatissimeque Correa, ut si quando aegritudinem doloresque retulero, ne ad maestitudinem scriptos interpretere, sed ut roges eum, qui omnia moderatur aequabilitatem ut praestet adferendum, et illam unicam uirtutem bonis omnibus plausibilem concedat, nempe tolerantiam. Tibi oculos amo, restitui exopto, acerrimosque redire quales fortasse adolescens habuisti aut, quoniam Dydimus esse recusas, uidendo lyncas superes, ut ingenii tui, studiorumque laudem aspiciat posteritas, et fructum industria, solertiaque adipiscare. Haec si nostro Lupo communicaris, me hortatore ipse augeat: et quoniam te alloqui potest quam saepissime, inci/39v/tet ad illius operis molitionem. Ne tu igitur, ut uereris, ad caecitatem festinato. Sperandum meliora, praesertim cum conatus tuos intelligamus eo pergere, ut habeant homines Lusitani Lusitanum, qui ueteres auctores explicando efficiet, ut necesse sit ad alienas prouincias commigrare: ut inde sint, qui Martialem lepidum illum quidem, sed obscurum explanent. Habes ruta caesa, ${ }^{58}$ et architectum, animum etiam optimum et uoluntatem, amicorum uota, iudiciaque nosti. Architectare, pergeque ut quam citissime te legamus. At ne qua iterum te suspicio quatefaciat, si nihil de ualetudine recenseam, sic habeto: ualeo, mi Emmanuel, quotidie habeo scholas, interpretorque

\footnotetext{
${ }^{58} \mathrm{cf}$. Festus 262.
} 
Danielem, et frequentior contionor, quam fortasse putant nostri, qui sunt in Collegio Antoniano. Ea uero causa fuit quod serius tuis literis responderem. Abierunt illi dies propter Christi Seruatoris natalitia feriati; quo primo licuit pergere in theologicum Lyceum, ad ianuam inueni qui tuas dedit. Rescripsisti celerrime, ut mihi, tibique satisfacerem: sed ternae per hosce dies habendae contiones /40r/ spatium dedere nullum, inuitum retardarunt. Quid amplius Emmanuel? Venio ad Lipsium. Epistulam quoque legi, recreauit, quod ad te uir doctissimus scripserit. Ad illum uiam esse, gratum mihi, et uolupe: et quod ille de Lusitania recte, id etiam uoluptati. Accusat bella, suscepisset ad nos profectionem, si arma quieuissent. Tranquillari illam prouinciam quis non optet, quae homines gignit illius modi? Ceterum, si ad eum scribis, dehortare ne, etiam si possit, huc pergat nauigare. Inueniet Lusitaniam, urbemque tuam non florentem, ut solebat, sed obsitam et pestilentiae malo frustratam. Malo eum apud Belgas dolere audiendo, quam in nostra calamitate maerere contuendo. Lipsium legimus, admiramur uiri diligentiam, ac doctrinam. Panegyrica ad nos non peruenere. Sed quoniam quid de eo sentiam requiris, in hac extrema cera hendecassyllaba demonstrabunt. Age, scribe, uale. Ede Martialem. A te doctissimum, et pudentissimum opus est abiturum. XVIII Kal./40v/ Ianuarii 1601.

Emmanueli Correae de Iusto Lipsio

Cum nuper Crucium tuum rogasses

Quam laudem dare Lipsio soleret

Respondit sibi Lipsium uideri

Cretaeum folio medente gramen

Natum reddere sauciis salutem.

Antiqui in triuiis uiri iacebant

Quorum uulnera nemo non dolebat.

At qui Paeonia manu chirurgi

Tractarunt, ope profuere nulla.

Dictamni ${ }^{59}$ tamen huius ut saporem

Et succum uetus aegritudo sensit

Sic fugit, bona Sospitas, ut esset

Illis, qui senio fugacis aeui

Tamquam deposito fores tenebant.

Iusto quid dabo laudis ? O ab Ida

Dictaea rosa lecta, uiue, tactu

In uitam exanimes tuo redibunt.

\footnotetext{
${ }^{59}$ Correxi ex Dictami
} 
[carta 60: Ibid. fls. 40v-42r]

Ludouico Crucio S. D. 60

Nae ego felix homo sum, felici illa dico /41r/ animorum parte qua amamus. Cui enim umquam tale contigit amicorum sodalicium, talis amor? Hinc Lipsius literarum pelagus, illinc Crucius a Musis factus, inde sexcenti adsunt alii, suo quisque modo, praecellentes. Hos ego mihi amicos malo quam aurum, quam fortunae gradum altissimum. Perit aurum, perit gradus ille. Soli amici manent, aeternumque manent, nullo interituri casu, nullo infortunio. Hinc ego librorum meorum horulam non mutauerim uel diuturno imperii sceptro, uel thiara Pontificia. His namque sua sunt taedia, sua scabra: ${ }^{60}$ Libris nostris summa semper uoluptas, summa gaudia; qualia mihi maxima tua haec ultima attulit epistula. Recreauit me, ita uideam, et ad maiora animauit, quam uires ipsae, quam animus ualeat. Sed hortaris tu, Cruci doctissime, imperas potius: accurrendum igitur ad falcem et demetendum sine metu. Quid plura? En Martialem in fornacem mitto, fundetur quanto ocius, exibitque quam fieri possit, prudentior, et pudentior, et ad amicorum gustum. Addam etiam alium, uel alios, non deterioris saporis, fellis tamen alicuius. Illud /41v/ quidem uehementer doleo, in saeculo adeo caenoso uiros uixisse, quos amo ob tersam latinitatem. $\mathrm{Ob}$ id illis aliquid condonandum, immo seculo. Quare adhibendi rastri, expurgandique, et e medio illo caeno extrahendae margaritae pretiosissimae. Haec tamen tempus, ut omnia. At te imperante quam citissime, et citius multo quam institueram. Nunc uale, ac Corream tuum pro Lipsio canentem audi, dum Lipsio non licet:

Quam uellem, meus ille Belga doctos

Tuos hendecassyllabos haberet!

Quo uultu legeret! Deus, quot illis

Amplexus premeret ! quot oscula! essent

Plura, quam memorant Catulliana.

Sed nefas, alio est locatus orbe

Longe seposito. Ergo nunc amico

Pro fido hos numeros deosculabor

Absque ullo numero. Meos amores

Dicam, et blanditias: sinumque laeto,

Dum negatur iter, tenebo laetus.

At nunc te, Ludoice, lux sororum

Quae celsae medium tuentur orbem,

Iusti nomine Lipsii uolentis

\footnotetext{
${ }^{60}$ Correxi ex. scabris
} 
Apello, ac socios, tuosque amicos, Foedus percutio perenne amoris. /42r/

Dextram Lipsius en libenter offert

Vos uestras dabitis, puto libenter.

O factum bene! o suaue factum! ${ }^{61}$

Quotquot uiuitis eruditiorum,

Vidistisne chorum eruditiorem?

[carta 75: Ibid. Als. 52r-53v]

Ludouicus Crucius Emmanueli Correae S. D. 75

Doluissem equidem, mi Emmanuel, si suspicari possem, moram harum litterarum molestiae aliquid tibi expectanti peperisse. Eras in expectatione fortasse, idque amici facere solemus. Cunctatior ego respondeo, idque uidebitur, amori nostro, et uirtuti tuae offecisse. At si te noui, diuinasti, opinor, non respondentem impediri eo malo, quo solo potuit impediri. Aegritudo fuit in causa, quae hoc Martio ita manus, digitosque occupauit, ut usum nullum reliquum fecerit laboranti. Nunc paululum recreatus calamum accipio, idque ex Lupo nostro forte discere potuisti. Cui cum deberem, non illi prius, quam tibi satisfacio. Quid ais, uir doctissime? Tuarum exordium exhilarauit. Felicem tu te praedicas; quod id, quod in humana uita longe praestantissimum habetur, sortitus sis. Ego ista felicitate tua te macte esse iubeo. Habes amicorum chorum, in quo Lipsius restim ducit, et sexcentos praecellentes, ut appellas, et me ei pulcherrimae choreae $/ 52 \mathrm{v} /$ participem esse uoluisti, eo tamen titulo ornatum, quem tribuis nimis liberaliter. Crucium a Musis factum ais; si fecissent, elegantiorem, mihi crede, tornauissent. Praerogatiua modestiore apud te in isto honestissimo sodalicio tuo esse uolo. Sed hoc tempore cur hoc gaudio non triumphem, cum repertum uideam uirum eruditum, tantum libris, et eruditioni tribuentem, ut ista auro, et Pontificum thiaris anteponat? Felix qui isto animo es. Facito, ut pecuniae exponantur in foro, istique honores cum libris, et eruditione permutandi ab Cominbrica celerrime conuolabunt; qui quae studendo docendoque compararunt, illi largientur, qui aurum, qui sacerdotia dederit opulenta, existimantes cum opibus et honore nihil nec optimas quidem disciplinas praeparari posse. Ad has nundinas non uenisse te optima rerum pretia intelligentem gratulor et uirtuti et felicitati tuae. Quod amicis aeternitatem promittis, id est, ut interpretor, constantiam, id quoque te unum inuenisse, magnae mi uoluptati esse debet. Quam enim sint huius aeui infidae amicitiae ignorare non potes. Tuas esse firmas, quis non admirando gratuletur? Philosopharis interdum, scabiem et taedia in principum esse dominatu commemoras. Ita est. Tu ex tuo Musaeo capis uoluptatem; eam

\footnotetext{
${ }^{61} \mathrm{O}$ factum... factum] $\mathrm{O}$ foedus superum, o suaue foedus ras..
} 
/53r/ aliunde uenari nec soles, nec necesse est. Quid? Paratam habes in omnes horas hilaritudinem, quae apud ordines honoratorum esse non solet. Fruere isto bono, quod opto tibi quam maxime diuturnum, modo in publicum redundet emolumentum. Et redundabit spero, cum nos spe tuorum operum impleueris. Prodeat tuus ille Martialis me etiam hortatore; et uideat Lusitania aliquem, quem Belgis illis, Batauisque opponat. Intelligantque illi, non solos esse se, qui bonas litteras retineant. Etiam Emmanuel Correa ostendet eas apud Olisiponem habere domicilium. Addes, quod illi fortasse non fecissent; pudentiorem exire iubebis illum ipsum Martialem, ut sine offensione legant omnes, ipsaque iuuentus addiscat elegantiam sine molestiae, pudorisque iactura. Corollarium etiam polliceris? Istuc est in communem sine fraude utilitatem laborare. Sed de felle non intelligo. Si sordes id signant, non metuo. Inciderunt illi, quiqui sunt in censorem, qui sordidissimum cum multauerint, ceteros etiam persona uestiat modestiore. At si fel acerbitatem prae se fert, sine. Scitum est illud tui Martialis

Infanti melimela dato, fatuasque mariscas:

Nam mibi quae nouit pungere, Chia placet. ${ }^{62}$

Ad extremum, quid sentiam de tuis hende /53v/cassyllabis reseruaui; lepidos, uenustos, aio, et Catullianos. Ita quoque Emmanuel? Ostendi lectissimis magistris, qui docent hic Conimbricae. Non dubitaui dicturos quae protulerunt. Hoc solum, et te Phoebus amat. Copiosior fuissem, si sineret imbecillitas. Sed uides, impolite scribis, manus mea. Et uinco, uicique animi uoluntate facultatem. Vale Conimbricae VII idus Aprilis 1601.

[carta 78: Ibid. fls. 57v-59r]

Ludouico Crucio S. D. 78

Et ego etiam ad scribendum tardus. Vt tua te chiragra, ita mea me caecitas remoratur. Auertat Deus mala haec, et nos nobis reddat, ut uiuamus securius, et scribamus diligentius; neue crebro pendeamus crebris suspicionibus, et metu qualis mihi maximus erat, cum tua accessit epistula, solitis tuis leporibus cumulata, et prospera ualetudine. Vera loquor, haec tua epistula summa me laetitia perfudit. Sensit domus mea, senserunt uicini, et amici, quotquot mihi in hac urbe, qui quidem plurimi sunt. Non tamen sensit Aluarus ille Lupus, meae pars maxima animae, immo mea tota anima. Aberat, Cruci doctissime, aberat; iam biduum in Portum discesserat Societatis uestrae iussu; sed sentiet quantocius, non enim illum hoc tantum gaudium celabo. Sed de illo prae /58r/ lacrimis non plura; de nobis igitur aliquid. Propensum illud meum in libros studium, quod ego felicitati tribuo proprium temporis infelicitatem tu ipse probas etiam; nescio tamen an serio uel ioco; ego serio quidem accipio. Nihil.

\footnotetext{
${ }^{62}$ Cf. Mart. VII, 25, 7-8
} 
Enim mihi magis serium, quam amicorum sodalicium, in quo potissimum libros constituo. Hunc tu locum amplificas in epistula, et philosophationem appellas, et bene; nam et nos iam aliquando huic studio horas aliquot impendimus, et nunc libentius, cum nostrates omnes occupatos uideamus in meris nugis, in meris potius furtis, caedibus, iniustitiis. Vtinamque esset pecunia, quae ad tuas illas deferretur nundinas, in tuam illam, quam commemoras, commutationem. At nunc fama est, regio edicto regni argentum omne congregari ad pecuniam cudendam; cuius tantam aiunt, futuram copiam, ut uel per uicos confluat aquae instar. Haec nunc de iis tantum. Quaeris de corollario nostro, et felle. Corollarium nostrum Catullus noster erit, et quidam alii in quibus etiam suum est fel, id est, saeculi sui amaritudo quaedam. Curabimus tamen, ut minus amarum sapiant. Quod hendecassillabos nostros lectissimi legerint uiri, laetor maxime, et tantorum uirorum iudicio multo magis; illud sciens certissime, quicquid $/ 58 \mathrm{v} /$ mihi iamdudum laudis accrescit, ex uberrimo bonae tuae indolis, et eruditionis fonte accrescere. Vale ac nos contra ama.

Olisipone VI Id. Ma. 1601

Complicata iam epistula, in monstrosa hac urbe monstrum hoc accidit: mulier quaedam triennium totum, et eo amplius, totam hanc urbem et equo et pede perambulabat, homo nomine et ornatu. Nomen illi, Emmanuel Sousa Coutinius, ornatus militaris, sericus tamen, et elegantissimus. Monasteria frequentabat, publica etiam adibat gymnasia, et colloquia publica, a primario quodam ductata uiro, uel potius, uiris, quos honestatis causa praetereo, et pudoris. Alia etiam faciebat nefanda, aiunt, facta quae referre pudet, dilatabunt alii. Cum autem diaboli soleae tandem rumpantur, et hae etiam ruptae sunt. Quid plura? A Doctore Gregorio d'Oliveira criminalium rerum iudice uiro et iudicio et manu suspiciendo dolo bino captus est formosulus iste adolescentulus, et delicatulus. Stricte in carcere custoditur, donec factum iudicetur strictissime. De ultimo rei euentu, ubi certum quid constiterit, certo adscri/59r/bam. Quid, quod et haec et similia neque scriptione indigent, neque admonitione. Fama uolat. Vale iterum et solue. 